\title{
PERSEPSI SYARIFAH DI HIDAYATULLAH BALIKPAPAN TENTANG SYARIFAH YANG MENIKAH DENGAN LAKI-LAKI NON SAYYID
}

\author{
Ummi Salami \\ Sekolah Tinggi Ilmu Syariah (STIS) Hidayatullah Balikpapan \\ ummisalami@gmail.com \\ Abidah \\ Sekolah Tinggi Ilmu Syariah (STIS) Hidayatullah Balikpapan \\ Abidah33@gmail.com
}

\begin{abstract}
Abstrak
Penelitian ini dilatarbelakangi adanya pelarangan seorang syarifah menikah dengan laki-laki yang bukan sayyid, dikarenakan nasab yang mulia yang ada pada syarifah itu sendiri akan terputus apabila syarifah itu menikah dengan yang bukan sayyid. Penelitian ini adalah penelitian lapangan (field research) yang bersifat kualitatif yang diuraikan secara deskriptif kualitatif. Setelah peneliti melakukan pengumpulan data mengenai Persepsi Syarifah di Hidayatullah Balikpapan tentang pernikahan syarifah dengan laki-laki non sayyid, terbagi menjadi dua persepsi. Persepsi pertama mengatakan bahwa syarifah boleh menikah dengan non sayyid dengan alasan pernikahan tersebut tidak ada pelarangannya dalam al-Qur'an dan Sunnah dan lebih mengutamakan ketaqwaannya, adapun persepsi kedua berpendapat tidak setuju dengan pernikahan antara syarifah dengan non sayyid karena akan memutuskan nasab yang dimiliki oleh syarifah tersebut, bahwa syarifah yang ingin menikah hendaknya mengutamakan nasab mulianya, apabila ditinjau dari sisi kafa'ah maka yang diutamakan adalah agama, karena kafa'ah merupakan syarat lazim bukan syarat sah.
\end{abstract}

\section{Keywords: : Pernikahan, Syarifah, Kafa'ah}

\section{A. Pendahuluan}

Islam merupakan agama yang sempurna sebagaimana telah diatur semua aspek kehidupan yang telah disyariatkan oleh pembuat syariat, salah satunya adalah pernikahan. Pernikahan adalah salah satu sunnah yang umum berlaku oleh seluruh mahluk Allah, baik manusia, hewan, tumbuh-tumbuhan dan semua yang diciptakan Allah k. Sebagaimana firman Allah k dalam surah Az-Zariyat ayat 49 sebagai berikut:

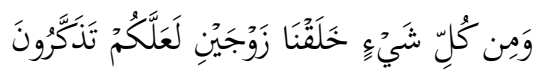

Artinya : " Dan segala sesuatu kami ciptakan berpasang-pasangan agar kamu mengingat( kebesaran Allah)"

Ada banyak hal yang membuat pernikahan itu terjadi yakni terjalinnya cinta, kasih sayang, keinginan dan kemampuan. Inilah yang menjadi alasan utama 
pernikahan itu berlangsung, karenanya merupakan kebutuhan biologis dan psikologis yang saling berkaitan, tidak dapat dipisahkan di kehidupan manusia.

Adapun dalam pandangan Islam pernikahan itu bukan hanya sekedar urusan perdata, bukan pula hanya urusan keluarga dan budaya. Tetapi masalah agama karena pernikahan itu dilakukan melalui syariat Allah dan sunnah Rasulullah saw serta dilaksana kan sesuai petunjuk-Nya dan sunnah Rasul-Nya. Oleh karena itu pernikahan bukan untuk mendapatkan ketenangan sesaat akan tetapi untuk selamanya. Demikian pentingnya institusi rumah tangga, syariat Islam memberikan tuntunan bukan saja bagi pasangan yang sudah menikah tapi jauh sebelumnya mulai dari proses pemilihan calon suami atau istri. Salah satu hal yang sangat penting untuk dipertimbangkan bagi calon pasangan yang akan menikah adalah kafā'ah atau kesepadanan antara calon mempelai karena kesepadanan adalah salah satu modal utama keharmonisan, sepadan dalam agama, harta, keturunan atau nasab, pendidikan dan pekerjaan.

Mengapa harus demikian, karena banyaknya pasangan suami istri yang gagal membina rumah tangganya disebabkan banyak perbedaan-perbedaan yang mencolok baik agama, sosial, keturunan dan hal yang menyangkut dalam kafā'ah. Maka dari itu seorang yang hendak menikah harus memperhatikan lebih tentang memilih calon pendamping hidupnya, untuk kelangsungan hidup ke depannya.

Dalam Islam wanita dinikahi karena empat hal yaitu karena hartanya, keturunannya, kecantikannya, dan karena agamanya sebagaimana sabda Nabi saw:

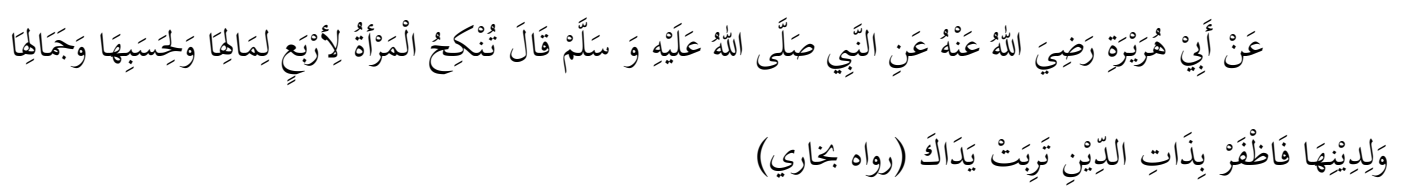

Dari Abu Hurairah a, dari Nabin, beliau bersabda: "Wanita dinikahi karena empat hal, karena hartanya, karena keturunannya, karena kecantikannya, dan karena agamanya, maka pilihlah karena agamanya niscaya kamu akan beruntung."

Islam lebih menekankan untuk menjatuhkan pilihan jodoh karena alasan agama, hal ini tidak lepas dari usaha bagi para calon suami maupun calon istri untuk mencapai kemaslahatan dalam mengarungi rumah tangganya, maka tuntunan kafā'ah sangat mendukung tercapainya tujuan tersebut.

Kafā'ah dalam pernikahan Islam menurut bahasa adalah sama dan setara. Setara antara pengantin laki-laki dan pengantin perempuan, yang kedudukannya 
sama-sama seimbang. Ada juga yang mengatakan bahwa kafā'ah adalah seorang lakilaki sebanding dan berkedudukan sama dengan calon istrinya baik dalam sosial, kekayaan dan sederajat dengan akhlaknya. Kafä'ah adalah suatu yang disyariatkan oleh Islam agar tercapainya pernikahan yang sakinah, mawaddah warahma.

Namun di dalam al-Qur'an tidak disebutkan secara jelas, hanya saja Islam memberikan pedoman agar yang ingin menikah untuk memilih pasangan yang baik dan benar, sebagaimana firman Allah pada surat An-Nur ayat 3:

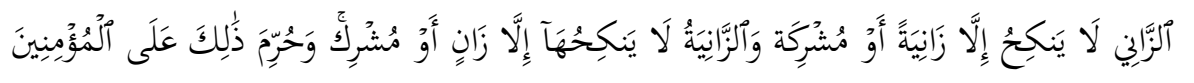

Ayat ini menjelaskan bahwa seorang mukmin tidak diperbolehkan menikah dengan seorang penzina ataupun seorang musyrik, karena seorang mukmin tidak setara dengan keduanya, dikarenakan agama adalah salah satu ukuran dari kafä'ah yang sangat dianjurkan.

Para Ulama dalam menetapkan kriteria kafā'ah memiliki pendapat yang berbeda-beda, namun mereka sepakat agama adalah yang paling diutamakan dalam berbagai hal. Tetapi berbeda dengan kalangan habib dan syarifah selain mengutamakan agama mereka juga menerapkan hal nasab dalam pernikahan, sehingga para syarifah yang menikah tidak diperbolehkan dengan selain sayyid.

Kalangan ini sangat menerapkan kafā'ah nasab dalam menikahkan putra dan putrinya. Seorang syarif/syarifah tidak diperbolehkan menikah dengan laki-laki selain sayyid karena takutnya nasab Rasulullah yang ada pada diri mereka akan terputus. Karena kemuliaan yang ada pada nasab mereka harus dijaga agar tidak terputus. sebagaimana hasil wawancara peneliti kepada salah satu syarifah yang ada di Balikpapan, yang mengatakan bahwa di dalam menentukan jodoh seorang syarifah harus dengan sayyid agar nasab yang ada pada mereka tidak terputus. Karena yang jadi masalahnya saat ada perkumpulan habib dan syarifah maka sang suami yang bukan dari kalangan mereka merasa terkucilkan bahkan ada yang sudah tidak dianggap sebagai syarifah lagi karena memilih menikah dengan non sayyid. Tetapi ada juga seorang syarifah yang mengatakan bahwa menikah dengan non sayyid itu sudah takdir yang tidak bisa dihindari.

Seorang syarifah yang dilamar oleh laki-laki yang bukan sayyid maka pernikahan itu tidak diperbolehkan walaupun syarifah dan walinya merestui, ini dikarenakan kemuliaan nasab yang ada pada diri mereka tidak dapat disamakan.

Sayyid dam syarifah merupakan sebutan untuk para laki-laki dan wanita arab, yang mana sebutan ini sangat berpengaruh dalam pernikahan arab, sehingga jika ada syarifah menikah dengan non Sayyid atau Sayyid menikahi wanita non Syarifah, 
biasanya terdapat ketidakseimbangan antara keduanya. Namun ini menurut pemahaman kebanyakan masyarakat, Padahal di dalam al-Qur'an telah dijelaskan bahwa semua manusia adalah sama yang membedakan hanyalah ketakwaan kepada Allah. Sebagaimana firman Allah swt dalam surah al-Hujurat ayat 13 yang berbunyi:

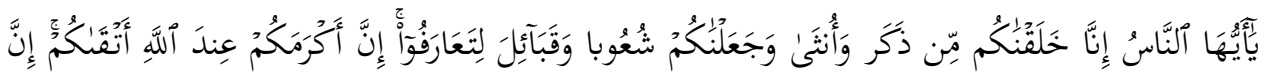

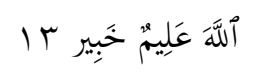

\section{B. Metode Penelitian}

Penelitian ini menggunakan penelitian lapangan (field Research) dengan terjun langsung pada lokasi penelitian tersebut juga mempelajari beberapa bahan tertulis antara lain buku, majalah, jurnal dan yang ada hubungannya dengan masalah yang diteliti.

Penelitian ini bersifat deskriptif kualitatif yaitu bertujuan untuk menggambarkan deskriptif secara sistematis, fakta akurat dan karakteristik mengenai populasi atau mengenai bidang tertentu. Metode penelitian deskriptif adalah metode yang menganalisis dan menyajikan fakta secara sistematik sehingga dapat lebih mudah dipahami dan disimpulkan. Penelitian ini adalah studi persepsi seorang syarifah tentang pernikahan syarifah dengan laki-laki non sayyid.

Data adalah hasil pencatatan dan temuan yang dimuat berbentuk file baik fakta maupun angka. Data yang peneliti gunakan dalam penelitian ini berupa: Persepsi syarifah di Hidayatullah Balikpapan tentang pernikahan syarifah dengan laki-laki non sayyid. Identitas responden terdiri dari nama, dan nama marga/fam. Apa yang menjadi landasan syarifah dalam menentukan pasangan nikah.

Teknik pengumpulan data yang digunakan dalam penelitian ini adalah: Observasi adalah pengamatan secara cermat, terhadap fenomenal sosial yang terjadi di lapangan. Wawancara adalah percakapan langsung yang bertujuan dengan maksud tertentu yang dilakukan oleh ke dua pihak secara sistematis mengenai permasalahan dan tujuan penelitian

\section{Kafa'ah dalam Pernikahan}

Kafä'ah berasal dari bahasa Arab yaitu dari kata كفى yang berarti sama atau setara, ${ }^{1}$ maksudnya adalah persesuaian antara laki-laki yang akan menikah kepada perempuan yang ingin dinikahinya, sama dalam hal kedudukan, akhlak, kekayaan

1 Amir Syarifuddin, Hukum Perkawinan Islam Di Indonesia (Jakarta: Kencana, 2006). 140 
agar rumah tangganya dapat sejahtera terhindar dari kegagalan. ${ }^{2}$

$K a f \bar{a}{ }^{\prime} a h$ itu disyariatkan atau diatur dalam pernikahan islam, namun dalil yang membahas tentang kafä'ah itu tidak terlalu jelas baik dari al-Qur'an maupun hadits Nabin, karena itu kafā'ah menjadi bahan perbincangan para Ulama mengenai kedudukannya dalam perkawinan maupun kriterianya. ${ }^{3}$ Sebagaimana Nabi $n$ telah memberi pelajaran kepada kita tentang tolak ukur kafä'ah, sesungguhnya yang menjadi tolak ukur maupun pelengkap adalah agama, yang mana jika menerapkannya akan tercapai kebahagiaan dalam rumah tangga sebagaima hadits Nabi n,:

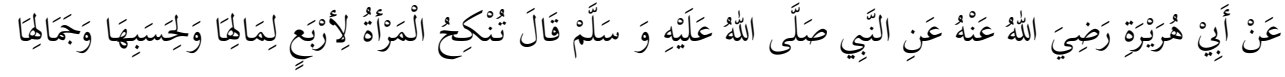

$$
\begin{aligned}
& \text { وَلِِيْنِهَا فَاظْفَرْ بِذَاتِ الدِّيْنِ تَبِتَتْ يَدَاكَ (رواه بخار }
\end{aligned}
$$

Dari abu Hurairah radiallahu 'anhu, dari Nabi shallallahu 'alaihi wassalam, beliau bersabda: " wanita dinikahi karena empat hal, karena hartanya, karena keturunannya, karena kecantikannya, dan karena agamanya. Maka piplihlah karena agamanya niscaya, kamu akan beruntung." ${ }^{4}$

Hadits ini menjelaskan bahwa dalam memilih pasangan hidup harus melihat keempat hal tersebut dari harta, nasab, cantiknya dan agamanya, namun Nabi saw sangat menekankan untuk menerapkan dalam hal agama. Adapun sebagian fuqaha memahami bahwa faktor agama saja lah yang dijadikan pertimbangan didasari dari hadis Nabi saw di atas "Maka carilah wanita yang taat beragama...", segolongan lainnya berpendapat bahwa keturunan sama kedudukannya dengan agama, begitu juga kekayaan. Sebagaimana dalam al-Qur'an dan Sunnah tidak menjadikan hal lain sebagai ukuran kafä'ah selain agama. ${ }^{5}$

\section{Kedudukan Kafä'ah dalam Pernikahan}

Para fuqaha empat mazhab dalam pendapat yang rajih mazhab hanbali dan pendapat mazhab Maliki dan pendapat yang paling zhahir dari mazhab Syafi'i bahwa $k a f a \bar{a} a h$ adalah syarat lazim dalam pernikahan bukan syarat sahnya nikah. Jika seorang perempuan yang tidak setara maka nikahnya sah. Para wali mempunyai hak dalam membatalkan pernikahan tersebut untuk mencegah rasa malu terhadap diri mereka, kecuali jika mereka jatuhkan rasa keberatan maka pernikahan tersebut menjadi lazim. ${ }^{6}$ Seandainya $k a f a{ }^{\prime} a h$ menjadi syarat sahnya pernikahan maka tidak sah

\footnotetext{
2 Bin Abdullah, Risalah Nikah, Trans. Agus Salim... 15

3 Syarifuddin, Hukum Perkawinan Islam Di Indonesia....140

4 Imam Abi 'Abdillah Muhammad Bin Ismail Bin Ibrahim, Shahih Bukhari, ( Semarang : 1981), 123

5 Ibnu Rusyd, Bidayatul Mujtahid, Trans Imam Gazali Said, (Jakarta: Pustaka Amani, 2007). 427

${ }^{6}$ Az-Zuhaili, Fiqih Islam Wa Adillatuhu, Trans. Abdul Hayyie al-Kattani. 218
} 
menikah tanpa adanya hal tersebut namun dari pemaparan di atas menjelaskan bahwa kafä'ah adalah syarat kelaziman seseorang dalam menentukan pasangan hidup, dan tetap sah orang yang menikah antara orang yang tidak sekufu.

\section{Kafā'ah Nasab}

Maksud dari nasab adalah asal usul seseorang tersebut yang berkenaan dengan latar belakang keluarganya menyangkut suku, budaya, dan status sosial. Dalam hal nasab manusia terbagi menjadi dua golongan Arab dan non Arab. Adapun Arab kufu satu dengan yang lain, begitu juga Quraisy sesama Quraisy, Sedangkan orang yang bukan Arab tidak sekufu dengan perempuan Arab.7 Dari konsep kafä'ah inilah yang melahirkan adanya hukum kafä'ah syarifan yang melarang syarifah menikah dengan laki-laki non sayyid karena dianggap tidak kufu dalam hal nasab.

\section{Tradisi Arab dalam Menjaga Nasab}

Bangsa Arab adalah bangsanya para penyair yang sangat fanatic terhadap kabilahnya masing-masing, maka dari itu mengetahui silsilah kabilah mereka atau yang dikenal dengan sebutan al-Ansab merupakan hal sangat penting sebab peperangan sering kali terjadi adanya perselisihan antara kabilah, maka dari itu sejak zaman bangsa Arab kuno hingga sekarang tradisi kesukuan di Arab sangat kental. Nasab atau silsilah keturunan merupakan perkara sangat penting bagi Arab karena nasab hak manusia ditegakkan dan dipelihara yang merupakan suatu kebanggaan terhadap kabilah, perhatian orang Arab terhadap nasab mendorong kuatnya fanatisme suku dan munculnya kelas-kelas sosial. ${ }^{8}$

\section{Sejarah Alawiyyin}

Secara umum kata 'Alawi digunakan untuk setiap keturunan Khalifah Ali bin Abi Thalib, pada perkembangannya di Yaman, Hijaz, Jazirah Arab dan berbagai Negara lainnya termaksud Indonesia kata ini kemudian dipakai untuk menyebutkan anak cucu Rasulullah n,, Alawiyyin atau Bani 'Alawi atau Ba'alawi adalah mereka yang bernasab kepada Rasulullah n melalui jalur kedua cucu beliau Hasan dan Husein menurunkan lagi melalui Sayyidina Alwi bin 'Ubaidillah bin Ahmad al-Muhajir bin Isa bin Muhammad al-Baqir bin Ali Zainal Abidin bin Husein, selain keturunan sayyidina Husein keturunan sayyidina Hasan juga disebut dzurriyan rasul mereka dikenal dengan sebutan Syarif, sedangkan keturunan Husein disebut dengan Sayyid. ${ }^{9}$ Awal

${ }^{7}$ Al-Juzairi, Fikih Empat Madzhab, Tras Faisal Saleh. 112

8 Neneng Magfiroh, Tradisi Kesukuan Arab sangat Kental, http://bincang-syariahtradisi arab.com. diakses pada 25 Maret 2020, 23:40.

9 Novel bin Muhammad Alaydrus, Jalan Nan Lurus Sekilas Pandang Tarekat Bani 'Alawi, 
terbentuknya kelompok keluarga dari imam Ahmad al-Muhajir yang berangkat meninggalkan Basrah bersama keluarga dan para pengikutnya pada tahun 317H/929M untuk berhijrah ke Hadramaut di Yaman. Cucu imam Ahmad yang bernama Alawi merupakan orang pertama yang pertama dilahirkan di Hadramaut, oleh karena itu anak cucu Alawi digelari Alawiyyin atau Ba'alawi yang bermakna keturunan alawi. Panggilan Ba'alawi bertujuan untuk memisahkan kumpulan keluarga dari cabang-cabang keluarga yang lain dari keturunan Nabi.10Adapun Alawiyyin mereka berakidah Ahlussunnah wal jamaah yang diikuti mayoritas muslim di Dunia, inilah akidah yang berpegang teguh pada al-Qur'an dan as-Sunnah ${ }^{11}$

\section{Kafā'ah Syarifah}

Pada prinsipnya masalah keturunan Nabin dan masalah sayyid syarifah sudah berada dalam perbincangan sejak berabad-abad silam, hal itu disebabkan adanya unsur kemulian dari Allahk dan Rasul-Nya yang menyertainya. Masalah kesepadanan di dalam pernikahan tidak dimonopoli oleh kaum Alawiyyin semata, syarat hukum kafa'ah itu sendiri telah diatur di dalam hukum perkawinan Islam dan menjalankannya dengan cara masing-masing. Syarifah adalah gelar kehormatan yang diberikan kepada anak cucu Rasulullah n keturunan Ali berdarah Fatimah. ${ }^{12}$ Dan mereka termaksud dalam Ahlul Bait sebagaimana firman Allahk dalam al-Qur'an surat al-Ahzab ayat 33 pada lafaz :

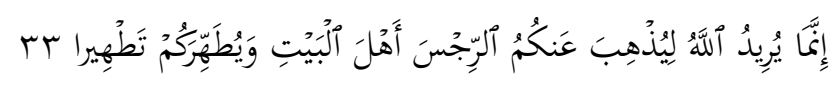

Yang dimaksud Ahlu Bait dalam ayat ini adalah istrri-istri, keluarga 'Ali, keluarga Ja'far, keluarga 'Aqil dan keluarga 'Abbas. ${ }^{13}$ Pada dasarnya ayat-ayat alQur'an telah menyebutkan keutamaan dan kemulian Ahlul Bait dan inilah yang mendasari pelaksanaan kafa'ah dalam pernikahan syarifah sebagaimana firman Allah dalam Q.S. al-An'am: 87

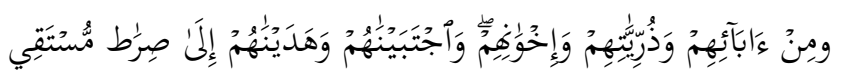

Ayat ini menjelaskan bahwa di antara keturunan para Nabi khususnya keturunan Nabi Muhammad saw dengan keturunan yang lain terdapat perbedaan

(Surakarta:Tim Taman Ilmu, 2006). 21

10 http://idWikipedia. Sejarah Alawiyyin,.id.com 25 Maret 2020, 23:40

11 Novel bin Muhammad Alaydrus, Jalan Nan Lurus Sekilas Pandang Tarekat Bani 'Alawi. 50

12 Novel bin Muhammad Alaydrus, Jalan Nan Lurus Sekilas Pandang Tarekat Bani 'Alawi, (Surakarta:Tim Taman Ilmu, 2006). 19

13 Abdullah Bin Muhammad Alu Syaikh, Tafsir Ibnu Katsir, Trans M. Abdul Goffar, (Jakarta: Pustaka Imam Asy-Syafi'i, 2016)...352 
derajat keutamaan dan kemuliaan. ${ }^{14}$ Adapun pelaksanaan kafa'ah yang dilakukan oleh keturunan Nabin berdasarkan oleh perbuatan Nabin yang menikahkan putrinya Fatimah az-Zahrah dengan Ali bin Abi Thalib, hal inilah menjadikan dasar keluarga Alawiyyin menjaga putrinya agar tetap menikah dengan laki-laki yang sekufu. ${ }^{15}$

Syarifah yang menikah dengan laki-laki non sayyid banyak para Habaib yang mengatakan sangat disayangkan, secara mazhab Syafi'i apabila syarifah itu menikah dengan laki-laki yang bukan dari keturunan Rasulullahn, dalam artian ia rela menggugurkan kafä'ah dalam nasabnya secara hukum pernikahannya sah namun dalam Mazhab Imam Hanbal pernikahan tersebut tidak sah, karena dalam salah satu riwayat Mazhab Imam Hanbal bahwa kafā'ah menjadi syarat sah pernikahan. ${ }^{16}$

Sebagaimana pendapat syaikh Abdurrahman al-Ba'alwi ${ }^{17}$ yang secara tegas melarang pernikahan syarifah dengan laki-laki non sayyid dengan alasan tidak sekufu dalam kitab Bughyatul Mustarsyidin IV:

"Masalah: Apabila seorang syarifah alawiyah yang dilamar oleh laki-laki yang bukan syarif, menurut saya tidak boleh terjadi pernikahan tersebut, meskipun perempuan dan walinya ridho, dikarenakan nasab syarifah yang shahih dan tidak ada yang menyamainya. Setiap keturunan Fatimah azZahrah padanya hak kerabat dekat maupun jauh, dan sungguh pernah terjadi pernikahan di makkah yang mulia antara non Sayyid dengan syarifah, maka pergilah seluruh sayyid kepadanya membantu ulama agar pernikahan tersebut tidak terjadi dan mencampakkannya sehingga para sayyid itu ingin mematahkan non sayyid tersebut sehingga mereka terpisah. Maka para syarif pun menetapkan bahwa tidak bolehnya syarifah menikah dengan non sayyid sampai ada yang mencabutnya. Berkata ulama fikih bahwa pernikahan syarifah dengan non sayyid itu sah dengan ridhonya dan ridho walinya. Maka bagi ulama salaf kami lebih untuk tidak membolehkannya, adapun pernikahan syarifah itu dibolehkan dalam keadaan darura t sebagaiman bolehnya memakan bangkai saat dalam keadaan darurat."18

Namun pernikahan syarifah dengan laki-laki non sayyid tidak terdapat dalil dari al-Qur'an dan as-Sunnah yang tegas melarang pernikahan tersebut, karena yang membedakan manusia satu dengan yang lain di sisi Allah k adalah ketakwaan. Adanya pelarangan pernikahan ini untuk menjaga dan memelihara kemuliaan nasab Nabi

14 Abdul kadir Alhamid, Kafa'ah Syarifah Dasar Hukum Perkawinana oleh Idrus Alwi Almansyhur, dipublikasikan, juni 06 2013, https,// ahlulbaitRasul.blogspot. ig.com. 21:24 am

15 Siti Salafiyah, " Pergeseran Paradigma Kafa'ah Nasab pada Komunitas Keturunan Arab di Pasar Kliwon Solo." (UIN Walisongo,2018). 46

16 Muhammad Arisyul Umam, "Pandangan Habaib Mengenai Perkawinan Wanita Syarifah dengan Laki-laki non Sayyid." (IAIN Surakarta, 2018). 119

${ }^{17}$ Seorang Mufti Hadramaut, yang lahir di Tarim pada tahun $1250 \mathrm{~h}$ dan wafat pada tahun 1320 h, seorang penuntut ilmu yang mengkaji mazhab Syafi'I, kitab bughyatul mustarsyidin adalh salah satu kitab himpunan fatwa yang beliau tulis saat sedang menjalani khalwat di Masjid Syaikh 'Ali bin Abu Bakar as- Sakrann.

18 Syaikh Abdurrahman Ba'lawi, Bughyatul Mustarsyidin,( Tarim: Dar Al Faqih,2006).cet IV 
saw.

Akan tetapi lebih utama dan lebih baik jika seorang syarifah menikah dengan sayyid yang memiliki iman dan takwa serta keistikamahan yang kuat. Karena barang siapa yang mengumpulkan antara keimanan, ketakwaan dan nasab maka itu lebih baik dan utama, menggabungkan dua kebaikan nasab dan iman. Karena siapa yang mempunyai nasab namun tidak memiliki iman, takwa dan keistikamahan maka nasab yang ia miliki tidak bermanfaat. ${ }^{19}$

\section{Dalil yang Mendasari Kafä'ah Nasab}

Hadits dari Abdullh Bin Umar:

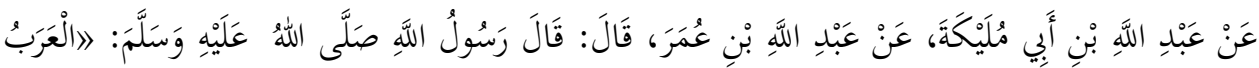

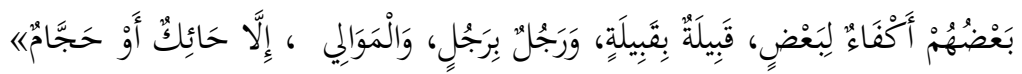

"Dari Abdillah Bin Abi Mulaikah dari Abdullah Bin Umar berkata: Rasulullah bersabda: Orang-orang Arab satu sama lain sekufu, satu kabilah dengan kabilah lainnya, satu daerah dengan daerah lainnya, seorang laki-laki dengan laki-laki lainnya, kecuali seorang tukang tenun dengan tukang bekam. ${ }^{20}$

Haits dari Hisyam Bin Ammar

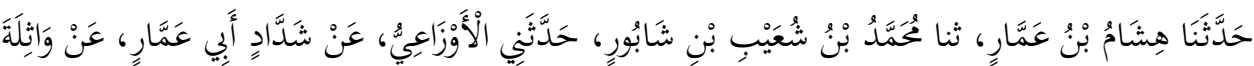

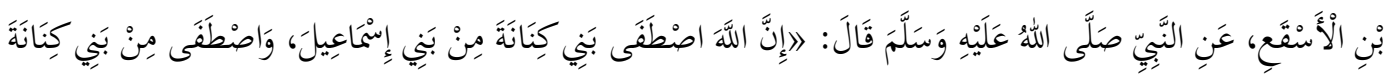

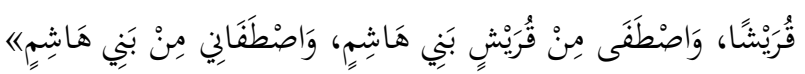

"Sesungguhnya Allahk telah memilih Kinanah dari anak-anak Isma'il dan memilih Quraisy dari kinanah dan memilih Bani Hasyim dari Quraisy dan memilih Aku dari Bani Hasyim."21

Akan tetapi para kritikus hadis dan tokoh yang mengkaji tentang hadis kafā'ah ini mencatat bahwa sebagian hadis kafā'ah ini tidak dapat dijadikan hujjah di antaranya al-Hafidz Baihaqi mengatakan dalam masalah kafä'ah banyak hadis yang tidak dapat dijadikan hujah. ${ }^{22}$ Sebagaimana al-Hafidz Ibnu Hajar al-'Atsqalani mengatakan bahwa nasab termaksud dalam kafä'ah tidak satu pun hadisnya kuat, dan

19 Shalahuddin 'Athiyyah As-sab'awi, I'tidalu wal wasatiyah syarah dari kitab 'Akidah Thahawiyah 'Akidah Ahlussunnah wal Jama'ah, (Beirut: Dar Al-Kalbu Al-Ilmiyah, 1971)

${ }^{20}$ Ahmad Bin Hasan Bin Ali Bin Musa Al Husraijirdi Al Hurasani Abu bakar Al Baihaqi, Sunan Shagir Baihaqi,Vol 38, (Pakistan: Darun Annasyar, 1989). No 2411, 474

${ }^{21}$ Abu Bakar Bin Abi 'Ashim Ahmad Bin Amru Bin Dhohaki Bin Mukhollid As-syaibani, Assunnah (Beirut: Al-Maktabah Al Islami, 1400). No. 1495.

22 Umar Sulaiman Al-Asyqar, Pernikahan Syar'i (Solo: Tinta Media, 2015).....239 
jika ingin menjadikannya sebagai hujah harus ditinjau lebih lanjut lagi. ${ }^{23}$

Seperti halnya Ulama kontemporer yang mana membahas tentang kedudukan nasab dalam pernikahan pendapat mereka tentang pernikahan syarifah dengan lakilaki non sayyid berkata Ibnu Bazz bahwa ini kesalahan yang besar dan kebodohan yang sangat menzalimi para wanita mensyariatkan yang tidak disyariatkan oleh Rasulullah saw, sebagaimana halnya bahwa Rasulullhah menikahkan orang terdekatnya tidak memandang Suku maupun ras, seperti Zainab binti Jahsyi yang dinikahkan dengan Zaid bin Haritsah seorang budak, Fatimah binti Qais yang menikah dengan Usamah adalah mantan budak. ${ }^{24}$ Demikian juga pendapat Ibnul Qayyim yang mengatakan bahwa kafä'ah dilihat dari sisi agama saja karena agama telah mewakili semua kriteria. ${ }^{25}$ Ini menujukan bahwa Rasulullah saw menikahkan orang terdekatnya melihat dari sisi ketakwaannya bukan dari sisi nasab dan lain sebagainya.

\section{Persepsi Syarifah Hidayatullah Tentang Pernikahan Syarifah dengan Laki- laki Non Sayyid}

\section{Syarifah MD}

MD menikah dengan laki-laki yang bukan seorang sayyid, adapun kedua orang tua MD tidak terlalu mementingkan mempermasalahkan tentang siapa yang menikah denganga MD,dan juga tidak mempermasalahkan perihal kafa'ah nasab saat menikah, dan kedua orang tuanya pun tidak melarang hal tersebut, MD meyakini bahwa masalah jodoh telah diatur oleh Allah swt, selama 21 tahun menikah MD dan suami menjalani kehidupan dengan baik-baik saja, harmonis sama seperti rumah tangga yang lain tidak ada bedanya. MD beralasan bahwa jodoh dan pasangan itu tidak harus mutlak dari yang sama nasabnya. Inilah yang membuat Md setuju dengan syarifah yang menikah dengan non sayyid Maka dari itu mengenai hal kafä'ah Md mengatakan harus dilakukan dan lebih mementingkan sekufu dalam hal agama bukan pada nasab.

\section{Syarifah JM}

Syarifah JM tidak terlalu mementingkan pernikahan kafa'ah dalam hal nasab karena baginya sekufu dalam hal agama itu lebih utama dan nasab tidak menjamin dapat meraih surga juga tidak menjamin kebahagiaan dalam rumah tangga. Walaupun di awal pernikahan syarifah JM, banyak keluarga yang tidak setuju dengan

23 Ibnu Hajar Al-Asqalani, Fathul Baari, Tras Amiruddin (Jakarta: Pustaka Azzam, 2008). 106

24 Muhammad bin Abdul Aziz Al-musnad, Fatwa Islamiyyah (Arriyadh: Darul Wathan, 1994).

25 Ibnul Qayyim Al- Jauziyah, Zadul Ma'ad (Lebanon: Resalah Publiser, 2000). 145 
keputusannya, apabilah syarifah JM menikan dengan yang bukan senasab dengannya, maka dianggap telah keluar dari pagar Rasulullah, sudah bukan lagi keturunan Rasululluah dan sudah dianggap keluar dari keluarga. Syarifah JM tetap mempertahakan hubungannya karean ia meyakini bahwa jodoh adalah takdir yang telah ditetapkan Allah sejak zaman ajali.

\section{Syarifah AD}

Syarifah AD adalah syarifah yang menikah dengan laki-laki yang tidak satu nasab dengannya, sejak kecil, keluarga syarifah $\mathrm{AD}$ tidak terlalu menekankan kafä'ah nasab, hanya saja kedua orang tuanya selalu menanamkan tentang syarifah harus menikah dengan sayyid. Namun kedua orang tuanya tidak menjelaskan secara detail tentang keutamaan seorang syarifah itu sendiri, sehingga AD tidak terlalu mementingkan kafä'ah nasab saat menikah. AD mengatakan bahwa keluarganya tidak terlalu sering bergaul dengan sesamanya sehingga pemikiran tentang pelarangan pernikahan tersebut tidak terlalu berpengaruh terhadap keluarganya. Keluarga $\mathrm{AD}$ menyetujui dan tidak melarang pernikahan tersebut. Menurut AD dalam menentukan pasangan yang harus diutamakan adalah ketakwaan seseorang tersebut.

\section{Syarifah KB}

Syarifah KB adalah syarifah yang menerapkan kafa'ah nasab dalam kehidupannya, syarifah KB adalah kakak dari syarifah $\mathrm{AD}$ walaupun mereka bersaudara tapi memilih cara pandang yang berbeda, syarifah KB memilih menjaga nasab mulia yang ada pada dirinya, berbeda dengan AD yang tidak terlalu mempermasalahkan tentang kafä'ah nasab karena dalam keluarganya jug tidak terlalu ketat dengan hal tersebut, namun syarifah KB mendapat pemikiran tersebut dari keluarga besarnya yang menerapkan kafä'ah nasab tersebut. Menerapkan kafä'ah nasab agar tidak memutus hubungan nasab dengan Rasulullah dikarenakan kafä'ah syarifah itu sendiri adalah kemuliaan, keistimewaan tidak semua wanita mendapatkan keistimewaan tersebut. Maka siapa yang mendapatkannya haruslah menjaga dan mempertahankan kafä'ah syarifah tersebut.

\section{E. Pembahasan}

Sebagaimana yang telah kita ketahui bersama bahwa seorang syarifah sangat dianjurkan menikah dengan sayyid agar nasab yang ada pada mereka tetap tersambung dengan Rasulullah, sebab jika syarifah menikah dengan selain sayyid maka nasabnya akan bercampur dengan nasab lain dan menjadi sebab terputuslah 
nasab mulia yang syarifah miliki. Demikianlah dengan tujuan yang mulia inilah yang membuat para Habaib dan Ulama Alawiyyin menfatwakan tidak diperbolehkannya wanita keturunan Nabi menikah dengan laki-laki yang bukan keturunan Nabi dilihat dari konsep kafa'ah yang bertalian dengan nasab, sebagaiman pendapat syaikh Abdurrahman al-Ba'alwi di dalam kitab Bughyatul Mustarsyidin yang secara tegas melarang pernikahan syarifah dengan laki-laki non sayyid dengan alasan tidak sekufu dalam nasab, pernikahan ini adalah sebuah tradisi yang telah lama ada.

Namun kebanyakan syarifah lebih memilih menikah dengan yang bukan sayyid, tidak mengikuti tradisi mereka dikarenakan beberapa faktor yakni syarifah tersebut tidak mengetahui asal usulnya atau nasabnya, tidak adanya penekanan dari orang tua tentang kafa'ah syarifah, kurang bergaul dengan sesama, lingkungan tidak terlalu mendukung, dan syarifah tersebut tidak terlau mempermasalahkan masalah $k a f a$ 'ah nasab dalam pernikahannya. Syarifah yang menikah dengan selain sayyid lebih mengutamakan sekufu dalam agama dilihat dari segi taqwa dan akhlaknya, karena inilah yang membuat syarifah tersebut menikah denga selain sayyid disamping karena mereka menyakini bahwa jodoh sudah di tentukan oleh sang Maha pencipta Allah .

Setelah peneliti melakukan pengumpulan data dari hasil wawancara di lapangan, maka peneliti menemukan persepsi antara syarifah di Hidayatullah tentang pernikahan seorang syarifah dengan laki-laki non say yid. Yakni empat syarifah yang menjadi responden peneliti, yang mana keempat syarifah ini mengetahui konsep $k a f a ̈ ' a h$ akan tetapi cara pandang yang berbeda dalam menjalankannya. Persepsi syarifah tentang pernikahan syarifah dengan laki-laki non sayyid telah peneliti uraikan dari reponden 1 sampai 4, ada beberapa persepsi yang sama mengenai pernikahan syarifah dengan laki-laki non sayyid apakah mereka setuju atau tidak setuju

Seperti halnya responden 1, 2 dan 3 mereka menyetujui pernikahan tersebut, karena pernikahan syarifah dengan laki-laki non sayyid ini tidak ada pelarangan khusus di dalam al-Qur'an, mereka lebih mengutamakan masalah ketaqwaaan, akhlak saat melaksanakan pernikahan dan tidak mempermasalah kan hal nasab, bukan karena mereka tidak mengetahui kemuliaan nasab yang ada pada diri mereka, akan tetapi keluarga dan lingkungan tidak terlalu memprioritaskan masalah kafä'ah nasab. Responden keempat mengatakan tidak setuju dengan pernikahan syarifah dengan laki-laki yang bukan sayyid dengan alasan apabila pernikahan tersebut terjadi maka akan memutus hubungan nasab dengan Rasulullah. Karena ia meyakini bahwa nasab ini adalah suatu keistimewaan yang tidak dimiliki kebanyakan manusia, maka 
seseorang yang memiliki nasab yang mulia ini haruslah menjaganya.

Kafä'ah Nasab yang berlaku pada pernikahan syarifah dengan sayyid pada masyarakat arab keturunan Nabi adalah sebuah tradisi yang telah berlangsung sejak lama dan turun temurun, sehingga pernikahan ini sudah menjadi sebuah hukum dikalangan mereka sebagai tradisi yang menyebabkannya menjadi bagian yang sangat penting saat menikah atau memilih calon pendamping hidup, sebagaiman sebagian ulama mereka Abdurrahman Ba'alwi beliau dengan tegas melarang pernikahan tersebut sebab dari itulah bagi syarifah yang menikah dengan laki-laki yang bukan sayyid, mereka akan dikucilkan bahkan dikatakan bukan lagi keluarga karena nasab yang ada pada syarifah tersebut akan terputus.

\section{Pernikahan Syarifah dengan Laki-Laki non Sayyid Ditinjau dari Hukum Islam}

Dalam Islam ada beberapa pertimbangan dalam menetukan jodoh diantaranya adalah kafä'ah, dalam pernikahan kafä'ah adalah msalah utama dalam proses pemilihan pasangan hidup karena kebahagiaan dan ketenagan dalam berumah tangga berawal dari cocoknya pasangn tersebut, suami sepadan atau setara dengan istrinya, karena Islam tidak menginginkan seorang wanita berumah tangga dengan seseorang yang tidak seagama dan akhlanya kurang baik maka dari itu demi keberlangsungan hidup bahagia sangatlah penting memperhatikan kafä'ah dalam pernikahan. Adapun kafä'ah para Ulama Fuqaha telah merumuskan kriteria dari $k a f a \bar{a} a h$ tersebut namun masih diperdebatkan, mayoritas Ulama mengatakan bahwa kafä'ah mencakup perkara agama, nasab, merdeka dan pekerjaan. Adapun masalah nasab imam Mazhab Syafi'i, Ahmad, hanafi mengakui adanya kriteria tersebut namun tidak bagi imam Maliki yang tidak mengakui adanya kriteria tersebut.

Konsep kafä'ah dalam nasab inilah yang melahirkan hukum kafä'ah syarifah dalam hal nasab, seorang syarifah yang menikah dengan laki-laki yang tidak satu nasab dengannya maka pernikahan tesebut tidak boleh dengan alasan akan memutuskan nasab mulia yang ada pada syarifa $h$ tersebut dengan Rasulullahn karena tidak sekufu dalam hal nasab, adapun landsan kafaah nasab yang digunakan adalah hadits dari Ibnu Umar

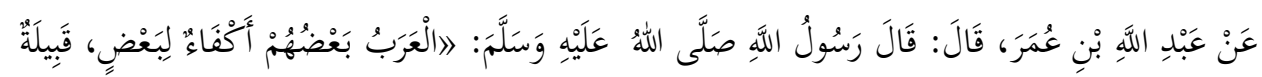

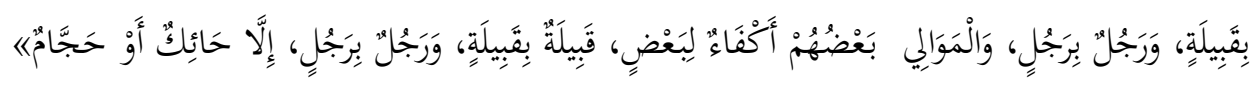

"Dari Abdullah Bin Umar berkata: Rasulullah saw bersabda: Orang-orang Arab satu sama lain sekufu, satu kabialah dengan kabilah lainnya, satu daerah dengan daerah lainnya, seorang laki-laki dengan laki-laki lainnya, 
kecuali seorang tukang tenun dengan tukang bekam."

Adapun hadis ini adalah hadis yang dhaif, sebagaimana Abdullah bin Abdurrahman al-Bassam dalam syarah bulugul mahram ${ }^{26}$ dikarenakan sanadnya terputus tidak sampai kepada Nabi sebagian rawinya tidak tsiqoh dan tidak dapat dijadikan hujjah dan dinilai munkar oleh Abu Hatim dalam kitab Subulussalam, ${ }^{27}$ dan isi hadits ini juga bertentangan dengan al-Qur'an karena agam Islam tidak memandang, ras, suku maupun derajat seseorang kecuali taqwa sebagaiman firman-Nya dalam al-Qur'an surah al-hujurat

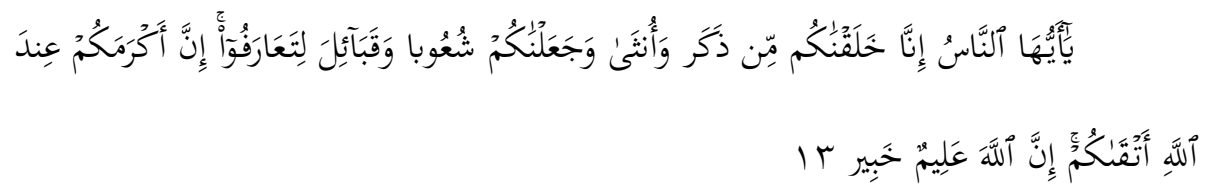

Dan dalam sebuah hadis Rasulullah bersabda

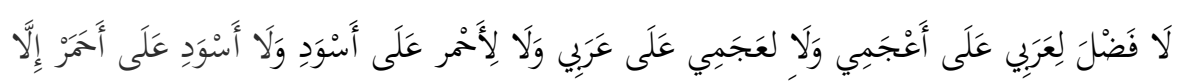

"Tidak ada kelebihan bagi orang arab atas orang ajam dan bagi orang ajam atas orang arab, tidak ada kelebihan bagi orang berkulit merah atas orang berkulit hitam, bagi orang berkulit hitam atas orang berkulit merah kecuali dengan ketakwaan"28

Dari ayat dan hadits di atas disimpulkan bahwa standar perbedaan seorang manusia adalah ketaqwaan tidak ada perbedaan Bani Hasyim dan suku Quraiys lainnya, tidak pula berbeda antara kabilah Quraisy dengan kabilah Arab, dan tidak adapula perbedaan antara bangsa Arab dengan non Arab

Larangan pernikahan ini menurut sebagian ulama bertentangan dengan kesejajaran kedudukan manusia secara menyeluruh, karena di dalam al-Qur'an tidak ada aturan tentang persamaan derajat manusia yakni tidak ada kelebihan antara satu dengan yang lain baik perbedaan suku bangsa status sosial maupun nasab, ${ }^{29}$ dari itu semua bukan menjadi sesuatu yang dapat di pertentangkan karena salah satu tujuan

${ }^{26}$ Abdullah bin Abdurrahman Al Bassam, Syarah Bulugul Maram, Trans Thahirin Suparta, (Jakarta: Pustaka Azzam, 2006). 369

27 As Shan'ani, Subulussalam, Trans Abu Bakar Muhammad (Surabaya: Al-Ikhlas, 1995). 464

28 Abu Abdullah Ahmad bin Muhammad Bin Hanbal, Musnad Imam Ahmad Bin Hanbal (Muassasatu Risalah, 2001). No 23489

${ }^{29}$ Nurul Fattah, "Hukum Pernikahan Syarifah Dengan Laki-Laki Non Sayyid," Al-Ahwal, Vol. 6, No. 2, 2013 (n.d.). 
utama manusia hidup adalah untuk saling mengenal dan menghormati satu dengan yang lain. Adapun seseorang yang tidak mau menikah sebab mementingkan nasab tidak di perbolehkan dilihat dari hukum pernikahan itu sendiri, nasab memang dianggap untuk menjadi pertimbangan dalam pernikahan, namun tidak dijadikan yang paling diutamakan. Kedudukan Kafä'ah secara mutlak bukan merupakan syarat dalam pernikahan, tapi merupakan syarat lazim. Adapun Syarifah yang menikah dengan laki-laki non Sayyid. Apabila kedua belah pihak, baik dari syarifah atau sayyid saling meridhai, maka sahlah pernikahan tersebut. Karena di antara hadits yang menjadi landasan kafä'ah syarifah tersebut sanadnya lemah dan beberapa ulama juga mengatakan jika ingin menjadikannya hujjah harus ditinjau lebih lanjut. Seperti halnya salah satu ulama kontenporer Ibnu Bazz yang tidak menyetujui kafä'ah nasab beliau mengatakan dalam kitab Fatwa Islamiah bahwa ini adalah kesalahan dan kebodohan yang besar dan pendzoliman terhadap perempuan mensayariatkan apa yang tidak disayri'atkan Allah dan Rasul-Nya. Begitu pula dalam KHI pada pasal 61 bahwa tidak sekufu tidak dapat dijadikan alasan untuk mencegah perkawinan kecuali tidak sekufu karena pe rbedaan Agama. Namun apabila seorang syarifah menikah dengan sayyid yang mempuyai keimana dan ketakwaan serta keistiqomahan maka itu lebih utama. Karena sesorang yang menggabungkan kebaikan nasab dan iman Allah lebih mengutamakannya.

Menurut peneliti persepsi syarifah di Hidayatullah Balikpapan tentang pernikahan syarifah dengan laki-laki non sayyid sesuai dengan konteks hukum Islam walaupun persepsi mereka tidak sesuai dengan sebagian Ulama Alawiyyin terdahulu, adapun pada masa Nabin tidak pernah di berlakukannya pernikahan dengan landasan nasab, dikarenakan Rasulullah menikahkan Fatimah Binti Qais dengan Usman mantan budak beliau, Rasulullah juga menikahkan dua putrinya dengan Usman Bin Affan, sementara itu Ali Bin Abi Thalib menikahkan putrinya, Ummu kultsum dengan Umar Bin Khattab yang berasal dari Bani Adi.

Adapun syarifah yang menikah dengan sayyid itu lebih baik demi menjaga keturunannya, sementara syarifah yang menikah dengan non sayyid tidak apa-apa dan tidak ada pelarangannya selama pernikahannya tidak menyelisihi hukum Islam yang merujuk pada al-Qur'an dan hadits, lebih baik lagi apabila seorang syarifah menikah dengan sayyid yang beriman lagi bertaqwa. Jika dilihat dari konsep kafä'ah pernikahan ini sah apabila keduanya setuju, namun jika salah satu dari keduanya tidak rela maka pernikahan ini boleh difasak, karena kafa'ah adalah syarat lazim pernikahan bukan syarat sahnya. 


\section{F. Kesimpulan}

Setelah peneliti melakukan pengumpulan data mengenai Persepsi Syarifah di Hidayatullah Balikpapan tentang pernikahan syarifah dengan laki-laki non sayyid, terbagi menjadi dua persepsi. Persepsi pertama mengatakan bahwa syarifah boleh menikah dengan non sayyid dengan alasan pernikahan tersebut tidak ada pelarangannya dalam al-Qur'an dan as-Sunnah dan lebih mengutamakan ketakwaannya, adapun persepsi kedua berpendapat tidak setuju dengan pernikahan antara syarifah dengan non sayyid karena akan memutuskan nasab yang dimiliki oleh syarifah tersebut, bahwa syarifah yang ingin menikah hendaknya mengutamakan nasab mulianya, karena merupakan keistimewaan yang tidak dapat dimiliki oleh banyak orang.

Ditinjau dari hukum Islam bahwa pernikahan syarifah dengan laki-laki non sayyid tidak ada dalil secara tegas melarangnya namun jika dilihat dari sebagian pendapat ulama Alawiyyin seperti Abdurrahman Ba'alwi beliau sangat melarang denga tegas pernikahan tersebut. Ditinjau dari sisi kafa'ah maka yang diutamakan adalah agama, adapun kafā’ah merupakan syarat lazim bukan syarat sah. 


\section{Daftar pustaka}

Abidin, Slamet. Fiqih Munakahat. 1st ed. Bandung: Cv Pustaka Setia, 1999.

Ahmad Bin Amru Bin Dhohaki Bin Mukhollid As-syaibani, Abu Bakar Bin Abi 'Ashim. Assunnah. Beirut: Al-Maktabah Al Islami, 1400.

Al Bassam, Abdullah bin Abdurrahman. Syarah Bulugul Maram, Trans Thahirin Suparta,. Jakarta: Pustaka Azzam, 2006.

Al Husraijirdi Al Hurasani Abu bakar Al Baihaqi, Ahmad Bin Hasan Bin Ali Bin Musa. Sunan Shagir Baihaqi. Pakistan: Darun Annasyar, 1989.

Al- Jauziyah, Ibnul Qayyim. Zadul Ma'ad. Lebanon: Resalah Publiser, 2000.

Al-Asqalani, IBnu Hajar. Fathul Baari, Tras Amiruddin. Jakarta: Pustaka Azzam, 2008.

Al-Juzairi, Syaikh Abdurrahman. Fikih Empat Madzhab, Tras Faisal Saleh. Jakarta: Pustaka Al-Kautsar, 2015.

Al-musnad, Muhammad bin Abdul Aziz. Fatwa Islamiyyah. Arriyadh: Darul Wathan, 1994.

Alu Syaikh, Abdullah Bin Muhammad. Tafsir Ibnu Katsir, Trans M. Abdul Goffar,. Jakarta: Pustaka Imam Asy-Syafi'i, 2016.

As Shan'ani. Subulussalam, Trans Abu Bakar Muhammad. Surabaya: Al-Ikhlas, 1995.

Az-Zuhaili, Wahbah. Fiqih Islam Wa Adillatuhu, Trans. Abdul Hayyie al-Kattani. Jakarta: Gema Insani, 2011.

Bin Abdullah, Sa'id. Risalah Nikah, Trans. Agus Salim. Jakarta: Pustaka Amani, 2002.

Fattah, Nurul. "Hukum Pernikahan Syarifah Dengan Laki-Laki Non Sayyid." Al-Ahwal, Vol. 6, No. 2, 2013 (n.d.).

Hanbal, Abu Abdullah Ahmad bin Muhammad Bin. Musnad Imam Ahmad Bin Hanbal. Muassasatu Risalah, 2001.

Rusyd, Ibnu. Bidayatul Mujtahid, Trans Imam Gazali Said,. Jakarta: Pustaka Amani, 2007.

Sayuti, Najmah. "Al-Kafa;Ah Fi Al-Nikah” (2015).

Sulaiman Al-Asyqar, Umar. Pernikahan Syar'i. Solo: Tinta Media, 2015.

Syarifuddin, Amir. Hukum Perkawinan Islam Di Indonesia. Jakarta: Kencana, 2006.

Zainuddin, Muhammad. "Pernikahan Syarifah Dengan Laki-Laki Non Sayyid [Studi Pendapat Habaib Pada Rabithah Alawiyah Jakarta." Islam Negeri Syarif Hidayatullah, n.d. 